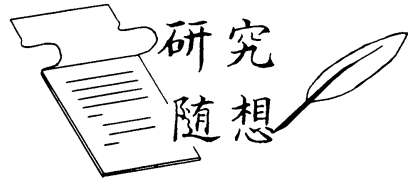

日本機械学会論文集 (B 編) 73 巻 736 号 (2007-12)

\title{
「燃焼」に燃えで*
}

\author{
新 \\ 岡 \\ 嵩*1
}

\section{Fascinated by Combustion Phenomena}

\author{
Takashi NIIOKA*2 \\ *2 Akita Prefectural University, Nakano, Shimo-shinjo, Akita-shi, Akita, 010-0195 Japan
}

\begin{abstract}
Key Words: Combustion phenomenon, Combustor, Combustion Fundamentals, Combustion Research, High Temperature Air Combustion (HiCOT)
\end{abstract}

燃焼の研究を, 大学院学生のころから数えると 40 年以上してきたことになる.いくら空々しくうそぶい たとしても「理解できた」とは言えないが，「楽しん だ」とは言える.ノーベル受賞者はほとんどが楽天的 な人達だというから，「楽しんだ」ことは自慢してい いかもしれない.ただ, 同時に「翻弄された」とも言 えるので威張れたものでもない。

何事も良い面と良くない面が表裏一体にあるのが一 般的だから，良くない面ばかり見て苦情ばかり述べて いる様は感心しない. 難関にぶつかったり, 予算が取 れなかったり, 意見が対立したりするのは, 研究をし ていれば当然避けて通れないはずであり，「翻弄され た」からこそ「楽しんだ」のであって，単に楽しんだ のであればもはや研究ではない. 40 年以上も同じこ とをしていると, どうやっても我田引水になってしま うが，めげずに書くことにする.

燃焼現象は，よく言われるように，流れ・熱・化学 反応の三者が相互干渉する現象だから典型的な複合現 象である.しかも，化学反応は類を見ないほどの強い 非線形性であるから, 奇奇怪怪な現象が生まれやす い. メ夕ン燃料の希薄な混合気内を細胞状火炎が伝ぱ する様や，管内の水素混合気内を毎秒 $1000 \mathrm{~m}$ を超え る速さでデトネーションが伝ぱする様は異常な現象に ほかならないし, 燃焼のこのような現象は枚挙に暇が

* 原稿受付 2007 年 9 月 25 日.

*1 正員, フェロー, 秋田県立大学( $010-0195$ 秋田市下新城中 野字街道端西 241-438).

[著者略歴］ 1940 年 8 月 24 日生まれ。扔もに燃焼工学, 特に固体 推進薬燃焼, 活性化エネルギ一漸近解析法, 微小重力燃焼, 高温空 気燃焼, 超音速燃焼などの研究に従事. 航空宇宙技術研究所, 東北 大学流体科学研究所を経て, 現在, 秋田県立大学理事・副学長. 東 北大学名誉教授.

E-mail : niioka@akita-pu.ac.jp
ない. 同じ条件で二つの燃焼現象が存在する場合など は，我々にとって魅惑的であり挑戦的ですらある。身 近な例として, 線香の燃焼領域の伝ぱは二通りある。 線香の先端に炎をつけながら進行する場合と, 炎がな いいわゆる無炎燃焼する場合の二つである，定常伝ぱ 問題を解析して二つの解が同時に出るであろうか. 有 炎燃焼のほうは定常だろうか. などと考えると複雑さ がよく理解できる.もっとも，解こうとすれば燃焼の 中でも特に困難な現象かもしれない.

このような複雑な燃焼現象が実際の燃焼機器でも生 じることが多く, 問題解決を迫られ，場合によっては 特異現象を活用したりしながら時代は進んできた。人 類が享受するエネルギーの $80 \%$ 以上は燃焼によって 得ている. 種々の角度から見てこれに代わり得るエネ ルギー源は当面ないであろうし，かといって，燃焼は 二酸化炭素を発生する地球温暖化の張本人である。筆 者が燃焼現象の基礎を研究しつつ直面してきた実際の 課題を二三比較しながら述べてみたい.よく燃焼学の 基礎と実用燃焼機器は乘離しているとの議論がある が，本来的に同じ現象であるはずだから関連があるは ずだという目が必要であり，そのような目を通して双 方から見極めていくことが大切である.

HMX (高融点爆薬) が性能向上のために固体ロケッ トに使われたことがある。 HMX は簡単に言えば最も 強い爆薬で，こんな危険なものをロケット推進薬に入 れるなどとはとんでもない話であった，実際，軽く吅 けば凄まじい爆発を起こす。火をつけると穏やかに燃 焼するのであるが，なぜ穏やかに燃焼するか，安全条 件は何か，ロケット性能はいかに向上するかなど，か なり基礎的に積み上げた，基礎的な背景があってこそ 実用に供される場合である。 
実用的には高性能になったが，なぜ高性能になった か明確に把握できないため商品化を躊踷する場合が燃 焼機器開発にはよくある。基礎を研究し根拠を示すと ともに，基礎を捉えたためにさらなる応用が可能にな ったのが高温空気燃焼技術であった。工業炉の廃熱を 回収し，これによって空気を予熱するとともに，排ガ スを混入することによって空気を希釈する方法であ る、同じ酸素量を確保するためには空気流速を上げな ければならない。これによって乱机は促進され均一燃 焼場形成などによって $\mathrm{NO}_{x}$ が著しく削減できただけ でなく，排熱回収がエネルギー効率を向上させた。市 らゆる角度から検証された基礎をもとに，この技術は ごみ焼却炉などに応用され, $\mathrm{NO}_{x}$ だけでなくダイオ キシンも大幅に隇少できた。

意外な現象のため事故が生じ，基䃈的な検証を迫ら れる場合もある. 原子炉内の各種管内を流れる水は放 射能によって極めて少量ではあるが水素と酸素に分解 する，長い時間の間に滞留し，何らかの原因で発火し デトネーションへと遷移すると管の破壊に至る場合が ある. 何が原因で発火するか, どの程度の濃度で滞留 すると燃焼に至り，どのような条件でデトネーション に至るかなどは基礎的に調べなければならない。水蒸 気で希釈された高温高圧の雾囲気におけるデトネーシ ヨン現象はまったく未知の世界であり，まさに基礎と 応用の双方から追及していかなけ机ばならなかった例 であり，現在ほぼ解決の方向にある。

基礎と応用がいかに相補関係にあるか実例を挙げて 説明した，当然であるが，基礎がしっかりしていない と確かなものはできないし，さらなる展開もできな い. 決して fundamental oriented を奨励しているわ けではなく，興味をもったものをしっかり研究しなけ ればならないし，しっかりした基礎でないと役に立た ない.すぐ役立つ研究はすぐ役立たなくなるのが研究 の宿命である，重ねて言えば，基礎と応用は結びつい ているという目が大切で, 双方から追いかけないと決 して良い結果が出ないことを強調したい。

実用燃焼機器を横目で見ながら基礎研究をするもの にとっていささか気になるのは, 最近の燃焼機器には
「火」が見えないことであるももちろん熱効率などを 考充意図的に見えないようにしているであろうし，そ れが技術の進歩であろう。しかし，若い学生などにも のづくりを奨励しながら最も魅力的なところを見せな い上うにするのは必ずしも領けない.「火」が見える ようにすることがどれほど人の興味を引くであろうか という視点もあっていい．些細なことではあるが，乃 うそくの炎がどれほどロマンティックであるかという ことを思い起こしてはどうだろうか.

燃焼は我々の最も大きなエネルギー源でありなが ら，同時に公害や地球温暖化の原因でもあり，時には 大災害の原因になる。諸刃の剣とは燃焼のことかと思 えるほどである。しかし，諸刃を許さない時代にある ことを人類は強く認識している。近年, 新エネルギー と称して期待感を増幅させているが, 実は最も大切な のは省エネルギーであることをより強く認識しないと 地球温暖化は止まらない。もちろん，新エネルギーは 試行錯誤して研究・開発を進めなければならないが, いずれも化石燃料に取って代わるにはまだ程遠い道の りである. 省エネルギーを強力に進めないと二酸化炭 素排出量は急速には減少しない.

橋梁の崩壞事故がアメリカで起きて問題視され，日 本でも点検が進められているが，予算はなかなか点検 修理には行かず, 新規の橋の建設に向かう. 例えが適 当かどうかは異論があるとしても，重礼て言うと，新 エネルギーあるいは再生エネルギーが現在のエネルギ 一需要を満たすまでには相当の年月が必要であるにも かかわらず，それまでの温暖化防止はどう進めるので あろうか。温暖化が危機的状況だとすれば, 省エネル ギーのほうが害質的にしかも確かに二酸化炭素削減に 一層寄与すると思うがいかがであろうか。ささらなる研 究は待つとしても, 古い燃焼機器を最新技術のものに 置き換えただけで二酸化炭素削減は膨大な量になる。 二酸化炭素回収も近々大きな課題になるであろう。 いずれも経済との調整が至難である. 今日までの機 械工学に照らして, 経済との調整などを考えなくとも よい画期的なエネルギー技術がすぐ見つかるとは考元 難いが，それでも諦めたくない昨今である. 